\title{
US NHANES Data 2013-2016: increased risk of severe obesity in individuals with history of juvenile idiopathic arthritis
}

\author{
Stephanie Merwin ${ }^{1 *}$ (D) Eleanor Mackey ${ }^{1}$ and Sangeeta Sule ${ }^{2}$
}

\section{Dear Editor,}

Juvenile idiopathic arthritis (JIA) is the most prevalent rheumatic disease of childhood. Children with JIA have an increased risk of obesity $[1,2]$, but it is currently unknown whether there are specific differences in risk for development of overweight/Class I obesity or severe obesity (Classes II and III) and whether there are differences in behaviors associated with weight management in adults with a history of JIA.

We used data from the National Health and Nutrition Examination Surveys (NHANES), a program of the $\mathrm{Na}$ tional Center for Health Statistics (NCHS) under the Centers for Disease Control and Prevention. NHANES data for the current study included demographic and weight data and Questionnaire data on Medical Conditions from 2013 to 2014 and 2015-2016 [3, 4].

Our sample included 121 respondents with reported history of JIA, diagnosed when the respondent was $\leq 16$ years old. The comparison group was a random sample of respondents without JIA drawn in a 4:1 ratio to the JIA group $(N=508)$. We performed comparison of medians using Mann Whitney Wilcoxon and proportions using Chisquare distribution. Simple and multivariable logistic regression analyses were used to determine the odds ratio (OR) of obesity class.

Those with JIA had an almost three-fold increased odds of Class II (OR: $3, p=0.005$ ) and Class III obesity (OR: 2.7, $p=0.002$ ). When controlling for age, gender, and race, respondents with JIA still had an increased odds of Class III obesity (OR: 3.4, $p=0.004$ ). Approximately $50 \%$ of JIA patients reported trying to lose weight

\footnotetext{
* Correspondence: smerwin@childrensnational.org

${ }^{1}$ Division of Psychology and Behavioral Health, Children's National Hospital,

111 Michigan Ave NW, Washington, DC 20010, USA

Full list of author information is available at the end of the article
}

in the past year as compared to $34.5 \%$ of those with No Arthritis $(p=.02$; Table 1$)$.

History of JIA carries a three-fold increased risk of severe obesity in adulthood, despite increased behavioral efforts to lose weight. Prospective research starting in childhood is needed to identify mechanisms of this relationship and avenues for prevention efforts to avert the development of severe obesity in adulthood. Given adults with obesity are at risk for poor health outcomes including cardiovascular disease, type 2 diabetes, pain, depression and anxiety, and early death [5], this area of research is in critical need of immediate attention. Without prevention efforts aimed at this vulnerable population starting in childhood, the risk of increased morbidity and mortality associated with adult obesity for those with childhood JIA is considerable.

\section{Abbreviations \\ NHANES: National Health and Nutrition Examination Surveys; JIA: Juvenile idiopathic arthritis; BMI: body mass index; NCHS: National Center for Health Statistics; OR: odds ratio}

\section{Acknowledgements \\ Not applicable.}

\section{Authors' contributions}

All authors were involved in literature search, writing, and had final approval of the submitted version. SS conceived the idea for the study and conducted analyses. SM contributed to generation of tables, formatting, and text revisions.

\section{Funding}

No funding was received for this study.

\section{Availability of data and materials}

The datasets generated and/or analysed during the current study are available in the National Health and Nutrition Examination Surveys (NHANES) repository, [https://wwwn.cdc.gov/nchs/nhanes/ContinuousNhanes/Default. aspx?BeginYear=2013] and [https://wwwn.cdc.gov/nchs/nhanes/ ContinuousNhanes/Default.aspx?BeginYear=2015].

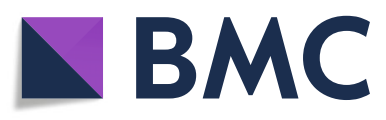

(c) The Author(s). 2021 Open Access This article is licensed under a Creative Commons Attribution 4.0 International License, which permits use, sharing, adaptation, distribution and reproduction in any medium or format, as long as you give appropriate credit to the original author(s) and the source, provide a link to the Creative Commons licence, and indicate if changes were made. The images or other third party material in this article are included in the article's Creative Commons licence, unless indicated otherwise in a credit line to the material. If material is not included in the article's Creative Commons licence and your intended use is not permitted by statutory regulation or exceeds the permitted use, you will need to obtain permission directly from the copyright holder. To view a copy of this licence, visit http://creativecommons.org/licenses/by/4.0/ The Creative Commons Public Domain Dedication waiver (http://creativecommons.org/publicdomain/zero/1.0/) applies to the data made available in this article, unless otherwise stated in a credit line to the data. 
Table 1 Respondent demographic information, BMI, and dietary behavior, NHANES data 2013-2014 and 2015-2016

\begin{tabular}{|c|c|c|c|}
\hline & $\begin{array}{l}\text { No } \\
\text { Arthritis } \\
N=508\end{array}$ & $\begin{array}{l}\text { Juvenile } \\
\text { Idiopathic } \\
\text { Arthritis } \\
N=121\end{array}$ & $\begin{array}{l}\text { Juvenile Idiopathic } \\
\text { Arthritis vs. No } \\
\text { Arthritis } \\
p \text {-value }\end{array}$ \\
\hline \multicolumn{4}{|l|}{ Demographic variable } \\
\hline Current Age, M (SD) & $\begin{array}{l}42.6 \\
(1.7)\end{array}$ & $44.4(1.5)$ & 0.3 \\
\hline Gender, \% female & 46.3 & 53.7 & 0.2 \\
\hline \multicolumn{4}{|l|}{ Race } \\
\hline$\%$ Caucasian & 60.2 & 75 & \\
\hline$\%$ African American & 13.3 & 10.6 & \\
\hline \% Hispanic & 14.7 & 6.6 & \\
\hline$\%$ Other & 11.8 & 7.8 & 0.02 \\
\hline $\begin{array}{l}\text { Heaviest self-reported life- } \\
\text { time weight (in kg), M (SD) }\end{array}$ & $\begin{array}{l}84.5 \\
(1.3)\end{array}$ & $97.6(2.9)$ & $<0.01$ \\
\hline Current BMl, kg/m², M (SD) & $\begin{array}{l}27.4 \\
(0.4)\end{array}$ & $30.6(0.8)$ & $<0.01$ \\
\hline $\begin{array}{l}\text { \% Overweight or obese, } \mathrm{n} \\
\text { (\%) }\end{array}$ & $\begin{array}{l}339 \\
(66.7)\end{array}$ & $94(77.7)$ & 0.02 \\
\hline $\begin{array}{l}\text { BMI 15-19.9: Underweight, } \\
\text { n (\%) }\end{array}$ & $29(5.7)$ & $4(3.3)$ & 0.3 \\
\hline BMI 20-24.9: Normal, n (\%) & $\begin{array}{l}140 \\
(27.6)\end{array}$ & $23(19)$ & 0.05 \\
\hline $\begin{array}{l}\text { BMl 25-29.9: Overweight, n } \\
\text { (\%) }\end{array}$ & $\begin{array}{l}162 \\
(31.9)\end{array}$ & 37 (30.6) & 0.8 \\
\hline $\begin{array}{l}\text { BMI 30-34.9: Class I } \\
\text { obesity, n (\%) }\end{array}$ & $90(17.7)$ & $17(14)$ & 0.3 \\
\hline $\begin{array}{l}\text { BMI 35-39.9: Class II } \\
\text { obesity, n (\%) }\end{array}$ & $28(5.5)$ & $14(11.6)$ & 0.02 \\
\hline $\begin{array}{l}\text { BMI } 40 \text { or higher: Class III } \\
\text { obesity, n (\%) }\end{array}$ & $29(5.7)$ & $19(15.7)$ & 0.0002 \\
\hline \multicolumn{4}{|l|}{ Dietary behavior } \\
\hline $\begin{array}{l}\text { Tried to lose weight in } \\
\text { the past year, } \mathrm{n}(\%)\end{array}$ & $\begin{array}{l}160 \\
(34.5)\end{array}$ & $46(50.1)$ & 0.02 \\
\hline $\begin{array}{l}\text { Changed eating habits, } \\
\mathrm{n}(\%)\end{array}$ & $72(14.2)$ & $23(19)$ & 0.2 \\
\hline Ate less, n (\%) & $\begin{array}{l}123 \\
(24.2)\end{array}$ & $43(35.6)$ & 0.01 \\
\hline Skipped meals, n (\%) & $27(5.3)$ & $13(10.7)$ & 0.02 \\
\hline $\begin{array}{l}\text { Switched to foods with } \\
\text { lower calories, n (\%) }\end{array}$ & $63(12.4)$ & $23(19)$ & 0.05 \\
\hline Ate less fat, n (\%) & $63(12.4)$ & $26(21.5)$ & $<0.01$ \\
\hline $\begin{array}{l}\text { Ate fewer carbohydrates, } \\
\mathrm{n}(\%)\end{array}$ & $60(11.8)$ & $26(21.5)$ & $<0.01$ \\
\hline Ate diet foods, n (\%) & $15(3)$ & $10(8.3)$ & $<0.01$ \\
\hline $\begin{array}{l}\text { Ate more fruits, } \\
\text { vegetables, salads, n (\%) }\end{array}$ & $89(17.5)$ & $32(26.4)$ & 0.02 \\
\hline $\begin{array}{l}\text { Ate less sugar, candy, } \\
\text { sweets, n (\%) }\end{array}$ & 69 (13.6) & $28(23.1)$ & $<0.01$ \\
\hline $\begin{array}{l}\text { Ate less junk food or fast } \\
\text { food, } n(\%)\end{array}$ & $78(15.4)$ & $24(19.8)$ & 0.2 \\
\hline
\end{tabular}

\section{Declarations}

Ethics approval and consent to participate

The project was approved by the National Center for Health Statistics Research Ethics Review Board (Continuation of protocol \#2011-17).

\section{Consent for publication}

Not applicable.

\section{Competing interests}

The authors declare no conflicts of interest.

\section{Author details}

'Division of Psychology and Behavioral Health, Children's National Hospital, 111 Michigan Ave NW, Washington, DC 20010, USA. ${ }^{2}$ Division of Rheumatology, Children's National Hospital, Washington, DC, USA.

Received: 7 April 2021 Accepted: 24 July 2021

Published online: 11 August 2021

\section{References}

1. Samad A, Stoll ML, Lavi I, Hsu JJ, Strand V, Robinson TN, et al. Adiposity in juvenile psoriatic arthritis. J Rheumatol. 2018;45(3):411-8. https://doi.org/10.3 899/jrheum.170598.

2. Schenck S, Niewerth M, Sengler C, Trauzeddel R, Thon A, Minden K, et al. Prevalence of overweight in children and adolescents with juvenile idiopathic arthritis. Scand J Rheumatol. 2015;44(4):288-95. https://doi.org/1 0.3109/03009742.2014.999351.

3. Centers for Disease Control and Prevention (CDC). National Center for Health Statistics (NCHS). National Health and Nutrition Examination Survey Data. Hyattsville, MD: U.S. Department of Health and Human Services, Centers for Disease Control and Prevention, [2013-2014], [https://wwwn. cdc.gov/nchs/nhanes/ContinuousNhanes/Default.aspx?BeginYear=2013].

4. Centers for Disease Control and Prevention (CDC). National Center for Health Statistics (NCHS). National Health and Nutrition Examination Survey Data. Hyattsville, MD: U.S. Department of Health and Human Services, Centers for Disease Control and Prevention, [2015-2016], [https://wwwn. cdc.gov/nchs/nhanes/ContinuousNhanes/Default.aspx?BeginYear=2015].

5. Dixon JB. The effect of obesity on health outcomes. Mol Cell Endocrinol. 2010;316(2):104-8. https://doi.org/10.1016/j.mce.2009.07.008.

\section{Publisher's Note}

Springer Nature remains neutral with regard to jurisdictional claims in published maps and institutional affiliations.
Ready to submit your research? Choose BMC and benefit from:

- fast, convenient online submission

- thorough peer review by experienced researchers in your field

- rapid publication on acceptance

- support for research data, including large and complex data types

- gold Open Access which fosters wider collaboration and increased citations

- maximum visibility for your research: over $100 \mathrm{M}$ website views per year

At $\mathrm{BMC}$, research is always in progress.

Learn more biomedcentral.com/submissions 